\title{
LEADERSHIP OF ERASMUS MUNDUS PHD STUDENTS IN MULTICULTURAL SOCIETIES: DEFINING AND BUILDING A COMPETENCE
}

\author{
Ielyzaveta Panchenko \\ Post-graduate Student, \\ Pavlo Tychyna Uman State Pedagogical University, Uman, Ukraine \\ ORCID: 0000-0003-3749-7164, e-mail: Lizapanchenko@gmail.com
}

This paper explores leadership from the standpoint of social constructivism. From this point, leadership is a complex notion that is studied in different ways and requires different definitions depending on the sphere, social circle, and situation where it is needed. It consists of knowledge, skills, and attitudes, which are formed and developed in the zone of proximal development - under assistance and in the process of communication. Four questions guided the investigation: Does the understanding of leadership depend on the cultural background? How is the understanding of leadership formed in a multicultural environment? How is leadership addressed in the Erasmus Mundus programme? As there is no universal definition, the author developed a definition of Leadership of Erasmus Mundus PhD students. For Erasmus Mundus PhD students of $A M U$, leadership is the interaction between leaders and followers among scholars educated at Adam Mickiewicz University of Poznan, that leads to positive changes in development of countries and reaching European standards. As it suggests, there should be three sets of leadership expression: ability to interact, ability to learn, ability to change. The focus group with Erasmus Mundus PhD students and the questionnaire for the alumni address the above mentioned.

The findings prove that though cultural background influences some shades of understanding the notion of leadership, "schemas" of leadership of representatives of different social groups have more in common, than differences. The main leadership skill for representatives of all the studied nationalities is dealing with people. The importance of other skills differs depending on the nationality of a person.

As to the specifics of forming understanding of leadership in a multicultural environment, it appears to be much more complex than the one in a monocultural environment. The Erasmus Mundus participants are all the time exposed to situations when they require assistance, and receive this assistance from people of various nationalities and positions. All those people become models of leaders that form their multicultural and multileveled understanding of leadership.

As leadership consists of knowledge, skills, and attitudes, the authors explain how the Erasmus Mundus programme influences all of them: during the programme, knowledge is formed in the zone of proximal development, which is, from the standpoint of social constructivism, the best way to gain and retain knowledge; during the programme PhD 
students find positive changes in their personal skills, as well as gain some new ones, which can be proved by the words of the focus group interview participants; the atmosphere of AMU university provides good conditions for interaction and learning, also promotes personal changes of the participants, and motivates them to change their societies, forming their positive attitude to leadership and making them act like leaders after the programme, providing those changes.

Key Words: leadership, multicultural society, social constructivism, Erasmus Mundus, PhD students.

У статті досліджено лідерство з точки зору сочіального конструктивізму. 3 чієї точки зору лідерство представлено як комплексне явище, яке досліджується по-різному і Вимагає різних Визначень, залежно від сфрери, сочіального оточення $i$ ситуачї, в якій воно застосовується. Лідерство складається зі знання, навиків $i$ ставлень, які формуються і розвиваються $b$ «зоні проксимального розвитку» - 3 допомогою і у процесі комунікації. У статті викладено авторсъкі відповіді на три запитання: (1) Чи залежить розуміння лідерства від культурного середовища? (2) Як розуміння лідерства формується у мультикультурному середовищі? (3) Як відбувається формуВання лідерства і програмі Еrasmus Мundus для аспірантів?

Ключові слова: лідерство, мультикультурне суспільство, сочіальний конструктивізм, Erasmus Mundus, аспіранти.

\section{Introduction}

The problem of leadership has been viewed from different perspectives. Since the 1940s there have been numerous attempts to explain the phenomenon with the use of behavioural approach, trait approach, situational approach, contingency theory, etc. Each of them focused on a particular aspect of leadership in general, or on leadership in a particular sphere, and analyzed its manifestations, situations to which leaders are exposed, as well as reasons contributing to a person's gaining a leadership position. This paper views leadership as a socially constructed phenomenon with the idea of showing how the knowledge of it is formed in the process of social interaction. Thus, it explores leadership from the standpoint of social constructivism or socio-cultural approach. Four questions guided the investigation: What is leadership from the standpoint of social constructivism? Does the understanding of leadership depend on the cultural background? What are the specifics of forming the understanding of leadership in a multicultural environment? How is leadership addressed in the Erasmus Mundus programme?

\section{Methodology of Research}

The research is based on 29 Erasmus PhD students, who have studied at Classical Philology Department of Adam Mickiewicz University of Poznan within EMINENCE and EMINENCE 2 Erasmus Mundus projects (2012-2017). They are from Ukraine, Armenia, Georgia, and Belarus. Also, in their classes, they have met and communicated with students from Belarus, Turkey, Spain, China, Japan, South Korea, France, Check Republic and other countries. So their leadership schemas have been exposed to the influence of all these nationalities.

As the focus of the article lies in fostering leadership skills in EMINENCE PhD exchange students, it seems reasonable to hear the voices of the project alumni. There are two main arguments that can be advanced to support the idea that this category of participants should be surveyed: 
- $\quad$ After completing the project, they can demonstrate if the project objectives have been met in terms of employability, cooperation and collaboration

- After the project completion, they have had some possibilities to reflect on the experience, their positions, as well as the roles of people encountered during the mobility project.

The data for the research have been gathered with the aid of the following instruments and procedures:

- $\quad$ Theoretical analysis of the definitions of leadership with the aim of comparing the keywords that are the most frequently used and superimposing them on the EMINENCE project aim. Thus, we have made a working definition of leadership in PhD Erasmus Mundus students which, in its turn, was taken into account when developing the empirical instruments to be used. As a result of theoretical analysis of the trait-based works on leadership, as well as comparing them with the traits implied by the project objectives, we have made the list of the leader's skills to be used in the empirical instruments for the research.

- $\quad$ The combination of qualitative and quantitative methods that is possible by a focus group with the current Erasmus Mundus PhD students and a questionnaire for the programme alumni. The principles underlying the approaches to the interview and the questionnaire will be grounded in the next section.

\section{Theoretical background to defining leadership in Erasmus Mundus PhD exchange students}

Robert N. Lussier says there is no universal definition of leadership because leadership is complex, and because leadership is studied in different ways that require different definitions (Lussier, 2015, p.33). The idea has been supported by a number of researchers (Lussier 2015; Copeland, 1942; Jennings,1944; Bass and Stogdill, 1981; Kanter, 1983; Weiss, 1986 and others). Nevertheless, it is possible to view leadership under peculiar circumstances, in my case, under the conditions of mobility funded by EMINENCE and EMINENCE 2 Erasmus Mundus Projects. What makes the project students a separate research group is their uniqueness. On the one hand, they all come from different Eastern neighbourhood countries (Ukraine, Armenia, Azerbaijan, Georgia, Moldova, and Belarus), and have different backgrounds. On the other hand, they are put in the similar circumstances, namely Adam Mickiewicz University as the host institution for all of them, their status as emerging researchers, similar multicultural community, even similar financial conditions.

In this paper, we put forward the definition for the leadership of PhD Erasmus Mundus students. In our definition we rely on the existing definitions, finding out their similar characteristics through the keywords, with further adding the principle characteristics peculiar to the projects included in their aim. The acronym of the project brings a message that the project targets at "eminence", understood as distinction, renown, reputation and importance of future project beneficiaries on their return to EaP societies their students and scholars educated abroad - so needed for the development of countries aspiring to reach European standards.

Table 1

Key Words based on some Leadership Definitions

\section{Definition}

Leadership is the influencing process of leaders and followers to achieve organizational objectives through change (Lussier 2015, p. 34).

\section{Key Words}

influencing process, leaders, followers, achieve objectives, change 
Leadership is the art of dealing with human nature.... It is the art of influencing a body of people by persuasion or example to follow a line of action. " (Copeland, 1942, p. 77).

Leadership thus appears as a manner of interaction involving behaviour by and toward the individual 'lifted' to a leader role by other individuals (Jennings, p. 432).

Leadership is an interaction between members of a group. Leaders are agents of change, persons whose acts affect other people more than other people's acts affect them... Leadership occurs when one group member modifies the motivation or competencies of others in the group (Bass, 1981, p.16).

Leadership is the existence of people with the power to mobilize others and to set constraints" (Kanter, 1983, p. 249).

Leadership refers to the top-level administrative executive and his/her dominant coalition of the organization, which is invested with the power, status, and resources to manipulate, interpret, and negotiate constraints and resources into policy" (Weiss, 1986, p.9).

Leadership is understood as the role behaviour of a specific group member who, more than other members, exerts some kind of outstanding, lasting, and positive influence on fulfilling the group's functions of problem solving or goal achievement and group maintenance (Misumi, 1985, p. 8).

Leadership is an influence relationship among leaders and followers who intend real changes that reflect their mutual purposes (Rost, 1993, p. 108). art, influence, persuasion, example, follow, action

interaction, behaviour, individual, leader

interaction, members of the group, change, affect, motivation, competences

people, power, mobilize, constrains

executive, coalition, organization

power, status, manipulate, interpret, negotiate, constrains, resources, policy

role behavior, group member, influence, fulfill, function, problem solving, goal, achievement, group maintenance

influence, relationship, leaders and followers, changes, mutual purposes

Having analyzed all the key-words from the definitions, we have noticed, that the most frequent are: follow/followers (4), influence (4), leader (3), change (3). Other words were used in two definitions (interaction, individual, achieve/achievement, constrains, example, process, group member/ members of the group, objectives, persuasion, power) or only one definition (action, affect, art, behavior coalition, behavior, competences, executive, fulfill, function, goal, group, interpret, maintenance, manipulate, mobilize, motivation, mutual purposes, negotiate, organization, outstanding, people, positive, problem solving, relationship, resources, role, status, team). Keeping this in mind, we put forward the working definition for leadership which is manifested in group interaction.

Leadership of Erasmus Mundus PhD students of AMU is interaction between leaders and followers among scholars educated at Adam Mickiewicz University of Poznan, that leads to positive changes in development of countries and reaching European standards.

According to socio-cultural approach, the foundations of leadership education are about helping students understand their definition of leadership and understanding leadership in their environments. They do this through debate and contest by analyzing leadership subjects from similar knowledge bases. Leadership development is likely to focus on skills that help students to develop their ability to persuade and inspire people in 
their leadership arenas. Crucially, it will address the way that students appear to other people (Billsberry, 2009).

The working definition suggests that there should be three sets of leadership expression: an ability to interact, an ability to learn, ability to change. That is why the questions of the interview and the questionnaire address the above-mentioned issues. The analysis of the given answers suggests the answer to the first question that guided our investigation: What is leadership from the standpoint of social constructivism?

\section{Theoretical background to defining the leader's traits in Erasmus Mundus PhD exchange students}

The given questionnaire partially implies the trait approach to leadership, with the principal difference that the traits are presented in interaction and through interaction. In socio-cultural approach, according to Grint (1997), developed by Sandberg (2001), leadership has dualistic ontology - the idea that there are two entities, the subject and the object, that are separate and independent of each other. From the position of leadership, the two entities are a person perceived as a leader and a person perceiving the individual. So the researcher has to be able to separate the two entities to explore independent qualities or attributes of both parties. Also, leadership is believed by social constructionists to have both objectivistic epistemology (there is a reality and that it is through people's interpretation that meaning comes) and individualistic epistemology (the individual is the prime creator of knowledge about reality) (Sandberg, 2001).

The questionnaire does not explicitly ask about a person's leadership skills. It is composed in the way that gets those surveyed present their attitudes through actions so that I could avoid the subjectivity of understanding the self a real leader, or an underestimated one.

As mentioned in The Social Construction of Leadership Education by Jon Billsberry (Billsberry, 2009) dualistic ontology gives validity to students as valued observers of leaders. It gives them the "right" to view, analyze, and criticize the leadership of others. Their views reflect their approach to leadership. Moreover, according to socio-cultural approach, instructors should always take into account the students' own backgrounds when discussing leadership. Also, independent contexts and people should be provided for observers to discuss (and contest) leadership. If the students discuss their own leadership situation, it contradicts the rule that object and subject must be kept separate.

The questionnaire inquires about the people the PhD students asked for assistance or consultancy in different situations, both formal and informal. These can possibly be qualified as leaders in a more general context. It encourages the surveyed students to characterize those people (who on the one hand remain anonymous; on the other hand are represented by countries, former status (during the mobility period), and current status), thus producing data for the analysis that enables us to answer the following research questions.

The options presenting the leader's traits have been selected from the list of traits composed as a result of the analysis of 10 leadership-relates sources (Gupta, 2005; Rowley, 2003; Gardner, 1993; Lussier, 2015; Ghiselli, 1971; Bass, 1990; Leslie, 2017; Growing leaders, 2017 etc.) The list of traits was compared with Erasmus Mundus Eminence objectives, and only those correlating with 3 key characteristics from working definition (ability to interact, ability to learn, and ability to change) were chosen. Then the chosen 15 leadership skills were used both in the questionnaire and focus group. The results of the traits analyses are described in table 2. 


\begin{tabular}{|c|c|c|}
\hline $\begin{array}{l}\text { Key characteristics } \\
\text { from the working } \\
\text { definition } \\
\text { (Guidelines for } \\
\text { applicants, 2017) }\end{array}$ & $\begin{array}{c}\text { Explanation through EM } \\
\text { objectives }\end{array}$ & Leadership skills \\
\hline Ability to interact & $\begin{array}{l}\text { This set of characteristics imply } \\
\text { leadership behaviour in formal } \\
\text { and informal situations in } \\
\text { Erasmus Mundus community at } \\
\text { MISH of Adam Mickiewicz } \\
\text { University }\end{array}$ & $\begin{array}{l}\text { 1. dealing with people } \\
\text { 2. encouragement of alternative } \\
\text { thoughts } \\
\text { 3. capacity to win and hold trust } \\
\text { 4. agreeableness } \\
\text { 5. building and mending } \\
\text { relationships } \\
\text { 6. putting people at ease }\end{array}$ \\
\hline Ability to learn & $\begin{array}{l}\text { It concerns gaining new } \\
\text { knowledge and skills that can be } \\
\text { applied at home university to } \\
\text { introduce change }\end{array}$ & $\begin{array}{l}\text { 7. observation skill } \\
\text { 8. being a quick learner } \\
\text { 9. need to achieve } \\
\text { 10. intelligence }\end{array}$ \\
\hline $\begin{array}{l}\text { Ability to change } \\
\text { (oneself and } \\
\text { society) }\end{array}$ & $\begin{array}{c}\text { Implies both: readiness to change } \\
\text { yourself and power to change } \\
\text { others }\end{array}$ & $\begin{array}{l}\text { 11. openness to experience } \\
\text { 12. the ability to adapt } \\
\text { 13. flexibility } \\
\text { 14. confidence } \\
\text { 15. initiative }\end{array}$ \\
\hline
\end{tabular}

According to the individualistic epistemology of leadership, the students have a right to interpret and assess leaders. More than this, students' thoughts on leadership are their truths. Helping students find their understanding of what leadership is and applying this to their situations becomes an important goal of leadership development. Also, there seems to be no compelling reason to argue that language at this stage is critical. It becomes an essential medium. The leadership idea is established through discussion and debate. Leadership development is focused on skills the students have to develop to persuade and inspire people in their leadership arenas. Also, it will influence the way they appear to other people.

\section{What is the specifics of forming leadership in a multicultural environment? The focus group results}

The focus group was held with four people, all present PhD Students of Erasmus Mundus Eminence II, studying at the Adam Mickiewicz University of Poznan. Two of them are from Ukraine and two from Armenia.

As the language pays an essential role in social constructivism, and as one of the important conditions of a focus group is making nice comfortable atmosphere for all the participants, the moderator spoke Russian as it is the common language that is best understood by all the participants, but the participants answered in languages that are most comfortable for them to speak.

The interview was designed to answer three subquestions: How do Erasmus Mundus PhD students interact? How do Erasmus Mundus PhD students learn? How do Erasmus 
Mundus PhD students change? As a result, it will help to answer two main questions: Is there any connection between leadership development and Erasmus Mundus Programme? What is leadership in the eyes of Erasmus Mundus PhD students of Polish and Classical Philology of Adam Mickiewicz University?

The interview contained both quantitative and qualitative data analyses. The qualitative part concerned open questions, while the quantitative one was possible by giving the participants 3 lists of leadership qualities (chosen by me after analyzing ten leadership related sources and applying them to the objectives of Erasmus Mundus Programme) and asking them to choose the ones appropriate for peculiar situations. In such a way we can build a hierarchy of most needed qualities for Erasmus students in different situations. But also these qualities can help us built a schema of a leader in the eyes of programme participants.

To answer the question "How do Erasmus Mundus PhD students interact?" the participants were asked to remember their first days in the programme and the way they were joining new cultural society and to think how their interaction changed since that time. Particular attention was paid to people they interacted with.

All the participants admitted that programme and academic coordinators were very helpful and they were the first people they consulted after arrival. The other people they interacted with were Erasmus students from Armenia and Ukraine.

Three people out of four said they easily joined Polish society and now feel part of it. The things that helped them were good language knowledge ( 2 people), and previous acquaintances as one of the students has a relative in Poznan (1 person). But they admit that they have not established any new durable relationship or friendship with Polish people. As one of the participants said, "Of course, we communicate. At classes, in the trams. But not more".

The fourth participant, though being a very sociable person, still finds herself out of Polish society, as her circle of friends consists of only Armenian and Ukrainian people. This can be caused mostly by a language barrier. It was also explained by lack of initiative both from the side of the student as well as Polish side. The third reason that was named was the special curriculum for Erasmus students, where most of the subjects are designed for foreigners. The fourth one admitted by the students was lack of integration activities organized by the Mobility office in the middle or by the end of the programme.

Also, the students were asked to choose qualities that help Erasmus Mundus $\mathrm{PhD}$ students interact. The results are as follows: dealing with people - 4, openness to experience -4 , building and mending relationships -2 , observation skills -2 , need to achieve -2 , intelligence -2 , the ability to adapt -2 , flexibility -2 , initiative -2 , encouragement of alternative thoughts -1 , being a quick learner -1 .

To answer the question "How do Erasmus Mundus PhD students learn?" the participants were asked to think of the academic process, in terms of its similarity to the one at their home universities; if not, what were the differences.

The students agreed, that being Erasmus students completely differs from being a regular student of AMU University, as regular students have an established schedule, they have groups, and they do not have an opportunity to choose subjects (or just extra ones). The only exception are MISHiS (Multidisciplinary Individual Studies in Humanities and Social Sciences, 2017) students that, like Erasmus, choose subjects by their own and join various groups.

Though the first choice of subjects appeared to be very challenging, all the students liked that ability to choose. As it was mentioned by one of the participants, "I never skip classes, because, first of all, I know that I have chosen them by my own and I need them, secondly, because they are really interesting". But only half of them could easily find in 
the suggested proposal ones appropriate to their research. The others whether had to look for them on various faculties, or choose subjects not directly connected with their research, but the ones improving their personal, professional, communicational, or research skills. One of the students said, "You are just shocked when you realize that you DO have a choice!". The other mentioned, "Students in my home university are a kind of oppressed, but here we have more freedom, and that's what I like".

All the students, with no exceptions, admit that attending classes at Adam Mickiewicz University is very interesting, innovative and engaging because of a great number of practical tasks. They also confess that Polish students seem to be much more motivated and autonomous than Ukrainian or Armenian ones, and they do not need that much control from a teacher.

At this point, the moderator asked about the relationship between students and teachers at home and Poznan universities. As mentioned by one of the participants, "At home we have a wall between teachers and students, but here all of them are equal partners", which was agreed by other two students. "Once I was hugged by our supervisor, as she was leaving abroad and we were not to see each other for a long time. That could never happen in Ukraine. I was so touched that I almost cried".

Also, the participants suggested the idea that there is a connection between travelling and seeing the world and being open and friendly to students. "For lots of dogmatic teachers being arrogant and showing off means being respected by the students. They just don't know that there are some other ways of being respected". But in smaller towns university teachers and even rectors, even the ones, who don't travel, can be really friendly.

Qualities that help Erasmus Mundus PhD students learn: need to achieve - 4, openness to experience -4 , being a quick learner -3 , intelligence -3 , observation skill -2 , the ability to adapt -2 , flexibility -2 , initiative -2 , building and mending relationships -1 , confidence -1 .

To answer the question "How do Erasmus Mundus PhD students change?" the participants were asked to reflect on their own experience. First of all, they were to think over if they had found any changes in themselves - their skills, behavior, attitudes - since the programme started. If the programme has not changed a student, she was asked to think of what was missing in it to provide those changes.

Everybody agreed that it had broadened the horizons. The first student found positive changes, like treating everything calmer than before. The other student finds that not every change in her is positive. Before the programme, she was too busy. Here, during the programme, she has more free time. "Now I leave everything for the last minute. Ive never done it at home. At home, I never needed time management skills, because I had no time to plan. Now I lack them here", she says. She also found new priorities in life. "The things I had been dreaming about since childhood, but couldn't afford because of poverty - I mean travelling - became real in Poland".

The third person says she has changed just in a way she wanted to. She says, "Only living in a country for a long time can really change you. It cannot be compared with tourism". She has become more independent, flexible, and organized. She saw a lot of good examples of behaviour she would try to use in the future".

The fourth person changed her attitude to problems, and she thinks that Polish society is the reason. Also, her appearance has changed, as she doesn't wear heels and uses less make-up. But inside she stayed the same. Her inner changes don't depend on a place.

Then the students were asked to think of the changes they would like to provide at home countries, cities and universities when they come back. 
One of the students says, "I would motivate our students to study. But unfortunately, I will not change my country. I will not provide all the students with a job after they graduate. That is the highest motivation". The second and the fourth students are sure that making classes more practical is a good idea. "The students studying Korean language go to Korea for summer, the ones studying Mediterranean history go to Balkan countries...". "I would make academic mobility really work, at least, inside the country".

Qualities that help Erasmus Mundus PhD students change: need to achieve - 4, flexibility -4 , openness to experience -3 , initiative -3 , observation skill -2 , being a quick learner -2 , the ability to adapt -2 , encouragement of alternative thoughts -1 , capacity to win and hold trust - 1, agreeableness - 1, building and mending relationships - 1 , intelligence -1 , confidence -1 .

As the leadership of Erasmus PhD students is viewed through their ability to interact, learn and change, we will make conclusions of the focus group results at those three levels:

- interaction - though three out of four students feel that they have joined Polish society, they most of the time communicate within their cultural group. Therefore, I cannot definitely point at any large visible interaction development;

- learning process - all the students admit acquiring new knowledge both at the university and in the streets of Poznan, as well as while travelling;

- change - though the students do not find many changes in themselves, but they all admit that their horizons were broadened, and some of them acquires needed or improved previously owned leadership skills. As to the power to change, all the participants are ready to bring some positive changes into their society.

Thus, leadership development is especially visible at the levels of knowledge and change. As for interaction, it is not that obvious. Nevertheless, the students made implicite suggestions of how to improve the programme to have more interaction: to change the curriculum for the one where Erasmus students most of the time joined Polish ones, and to organize more integration activities in the middle or by the end of the programme.

As for the leadership schema, leader's patterns of behaviour and attitudes can be taken from four things:

- descriptions of positive examples of existing leaders (leaders can combine work or study with personal life, they should be nice, friendly, and open to people, they should treat others as equals, and not be afraid to lose)

- opposites from negative exampled (they should fight against corruption and other negative things, also they should never show off or be arrogant)

- from skills participants, they lack, but wish to possess (they should be confident of themselves, and their confidence should not depend on appearance or closing, they should also possess time management skills)

- from changes described by the participants and new skills, they developed (independent, flexible, and organized, broaden horizons, being motivating, giving good examples, be a good student or a citizen of a country, treat everything calm).

As for the leadership skills, from the point of view of the focus group participants, they are as shown in the bar chart (see picture 1) 


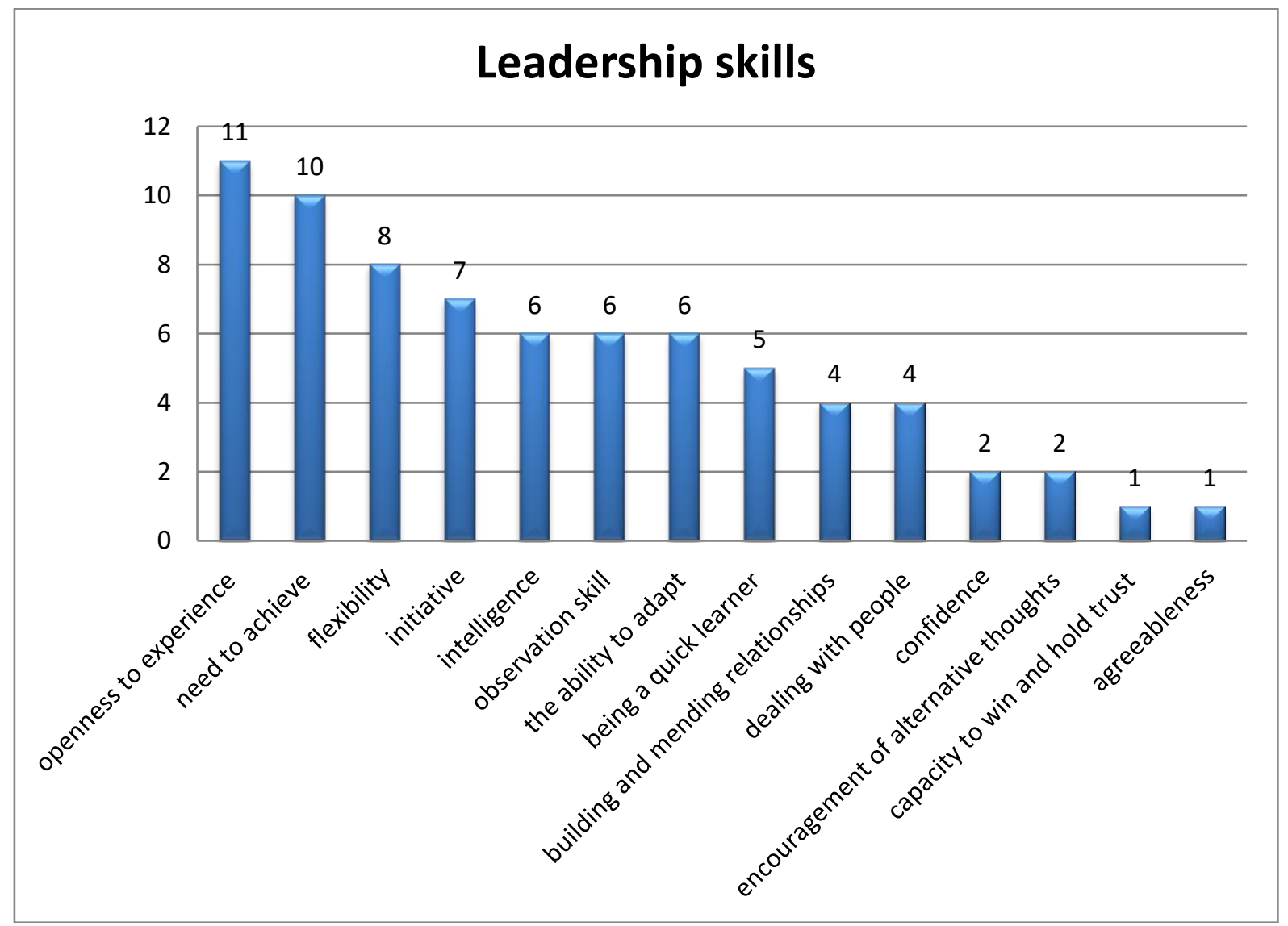

\section{Picture 1}

Erasmus Mundus PhD leadership skills as defined by focus group participants

And, finally, in analyzing participants' idea of leadership we should take into account their background. As was mentioned by the students, in Ukraine, for example, education lacks practical tasks and is much more theory-based, in Armenia, there is the biggest percentage of dogmatic teachers among the three countries, which is just a bit less presented in Ukraine. Also both in Ukraine and Armenia students are not as motivated as Polish ones, because the chance of finding a proper job is much lower. Of course, the life level also influences people's priorities, self-confidence, as well as confidence in the future. Owing to lower standard of living, average Ukrainian and Armenian people cannot spend as much money as Polish ones on travelling or self- development.

But from the results described above, we can state that, though cultural background of the participants is different, they all have similar attitude to leadership, giving similar examples of positive leaders and admitting existing problems.

Summing up all that was said by the participants and most popular skills they had chosen from the lists, we can state that a leader is a person, who is open to people and new experience, has a need to achieve, is flexible and initiative.

\section{How are leaders and leadership understood by Eminence alumni? The results of the questionnaire}

As various definitions of leadership show its multi-faceted nature, it can be viewed from the perspective of Triangle of Success (Edmunds, 2015) which consists of knowledge, skills and attitude.

Knowledge concerns first person's having in mind a model of a leader in his sphere or social group. The second is aimed to distinguish leadership features the individual has. 
The third one propounds the view that no leader is made without relevant circumstances, in which he can show his leadership skills, as well as without awareness of the importance of being a leader, and willing to become one.

Knowledge refers to students' understanding what is leadership. We assume, that Erasmus students do not form the common idea of leadership among them, but they face some patterns of leadership among their peers, teachers, or other representatives of social environment, and in such a way they form their leadership idea. It is based both on their native social background, as well as on the social environment they belong to during the mobility period.

For example, if people have never been abroad and have never spoken to representatives of other nationalities, all their models of leadership are likely to be very subjective and limited. The more nationalities the person faces, the more social environments the person gets into, the broader the person's world outlook becomes and the more objective and proper to other environments the leadership model becomes.

This can be viewed in terms of Schema theory introduced by Piaget in 1923 (Thorndyke, 1981). A person makes a kind of an unconscious (or seldom conscious) investigation, where the initial "schema" is the leadership model based on personal experience at home country. A new schema is formed when people face representatives of other nationalities and compare their leadership models to the initial schema. In this moment they experience disequilibrium, and after assimilation information, they expand their understanding of leadership and form a new, wider and more objective, schema. The more times it happens, the wider the leadership schema is. By the way, at the stage of disequilibrium, a role of program supervisors or other target university or social representatives is very important, as sometimes Erasmus students will seek for reinforcement in order to make new schema features assimilate with the previous ones.

Also in his works Lev Vygotski (Vygotsky, 1980, p. 86) describes "The zone of proximal development", which is the distance between the actual developmental level as determined by independent problem solving and the level of potential development as determined through problem solving under (adult) guidance or in collaboration with more capable peers.

Applying this knowledge to leadership studies, we can consider, that development of leadership in the zone of proximal development happens in the best way, when a person has 1) someone`s guidance and/or 2) communication with peers.

Overall in AMU, 29 PhD students took part in the Erasmus Mundus Programme in 2012-2017: 17 from Ukraine, 7 from Georgia, 3 from Belarus, and 2 from Armenia.

As 5 students ( 2 from Armenia and 3 from Ukraine) are still having their mobility, we asked them to take part in our focus group.

For the others, a questionnaire was designed. We sent it to 24 people: 14 Ukrainians, 7 Georgians, and 3 Belarusians. We have received the answers from 16 people - 11 Ukrainians, 2 Georgians, and 3 Belarusians.

This questionnaire was to answer several questions:

- Is leadership a universal notion or do different occasions require different kinds of leaders?

- Do people appeal for help more to formal or informal leaders?

- Do people appeal for help to people of their nationality?

- Do the people have longitude relations with their leaders after the programme?

- What set of leadership skills do Erasmus Mundus students value?

- Are these skills universal or specific according to the situation?

- Do the required skills depend on the nationality of the interviewed person? 
- Have the Erasmus Mundus objectives been met in terms of employability, cooperation and collaboration?

- What is leadership in the eyes of Erasmus Mundus PhD students studying in AMU, Poznan?

Is leadership a universal notion or do different occasions require different kinds of leaders?

Some questions concerned the amount of people our respondents asked for help in six various situations, and most of participants wrote they appealed to only three (6 participants) or four ( 6 participants) people. Three respondents - to 5 people and only one person appealed for help to 6 people - each time for a different person for every specific situation. From here we can state that though leaders are not universal, still one person can be a leader in a couple of various situations or spheres.

Do people appeal for help more to formal or informal leaders?

Some questions were designed to answer this question. As the results show, in most situations, people apply for help to formal leaders, excluding the cases of personal problems and informal meetings. Though even in the latter situations small amounts of participants consult programme coordinators (mostly Georgians and Belarusians). Also, only Ukrainian appealed to informal leaders in situations other than personal problems or informal meetings.

Do people appeal for help to people of their nationality?

As the evidence shows, first of all, most of the time people still prefer consulting people of their nationalities (arithmetic mean from all the situations - 66\%). The only exception is the information about Polish culture and habits, where main source of information is Polish people.

Moreover, there are some specifics of each nationality. In $50 \%$ of the situations Belarusians consulted leaders belonging to their nationality, in the other $50 \%$ - other nationalities (Polish and Georgians). Ukrainians consulted Ukrainians in 60,7\% of situations, and in the other 39,3\% - Armenian (14,3\%), Polish (14,3\%), Belarusians (3.6\%), Georgians (3.6\%), and Moldovans (3.6\%). Georgians in all the cases consulted only people of their nationality.

Do the people have longitude relations with their leaders after the programme?

People still keep in touch with $68,8 \%$ of people they consulted concerning Polish traditions, research, and informal events, and $75 \%$ of people they appealed to concerning general and academic issues. But the biggest percentage of long term relations concern the ones with people applicants appealed to when they had personal problems $-93,8 \%$.

What set of leadership skills do Erasmus Mundus students value?

Based on the answers to the questionnaire, we can state, that the most universal skill is dealing with people, as it was chosen by more than a half (from $60 \%$ to $81,3 \%$ ) of respondents in 5 out of 6 situations. Then it is followed by intelligence (from 53,3\% to $73,3 \%)$, which was chosen in 3 situations. The majority of respondents chose confidence (53,3\%-56,3\%) and flexibility (50\%-60\%) in 2 situations, also agreeableness (50\%) and capacity to win and hold trust (50\%) in 1 situation.

Are these skills universal or specific according to the situation?

Here we will mention only skills chosen by more than $50 \%$ of the respondents, to pay attention only to the main ones. The three top skills for general issues are dealing with people (chosen by 73,3\% of respondents), flexibility $(60 \%)$, and intelligence $(53,3 \%)$. For information on Polish traditions the main skill is dealing with people $(60 \%)$. For academic assistance the leading skills are intelligence $(68,8 \%)$, dealing with people $(62,5 \%)$, confidence (56,3\%), and capacity to win and hold trust and flexibility (50\%). In research intelligence still stays leading $(73,3 \%)$, and confidence $(53,3 \%)$ is viewed as important. In people`s ability to solve personal problems the respondents value the skills of dealing with 
people $(68,8 \%)$ and agreeableness $(50 \%)$. In organization of informal events dealing with people is understood as the most important skill (81,3\%).

Do the required skills depend on nationality of the interviewed person?

Though dealing with people is the first required skill in the answers of respondents of all nationalities, there are still some differences concerning other skills. For Ukrainians flexibility is more important than for Georgians and Belarusians. Belarusians value the skills of putting people at ease and building and mending relationships much more than the others. As for Georgians, comparing to other nationalities, they showed great interest in such skills as encouragement of alternative thoughts, confidence, and agreeableness. Also the interesting fact was the one, that Belarussians didn't use the need to achieve in any of their answers (see picture 3).

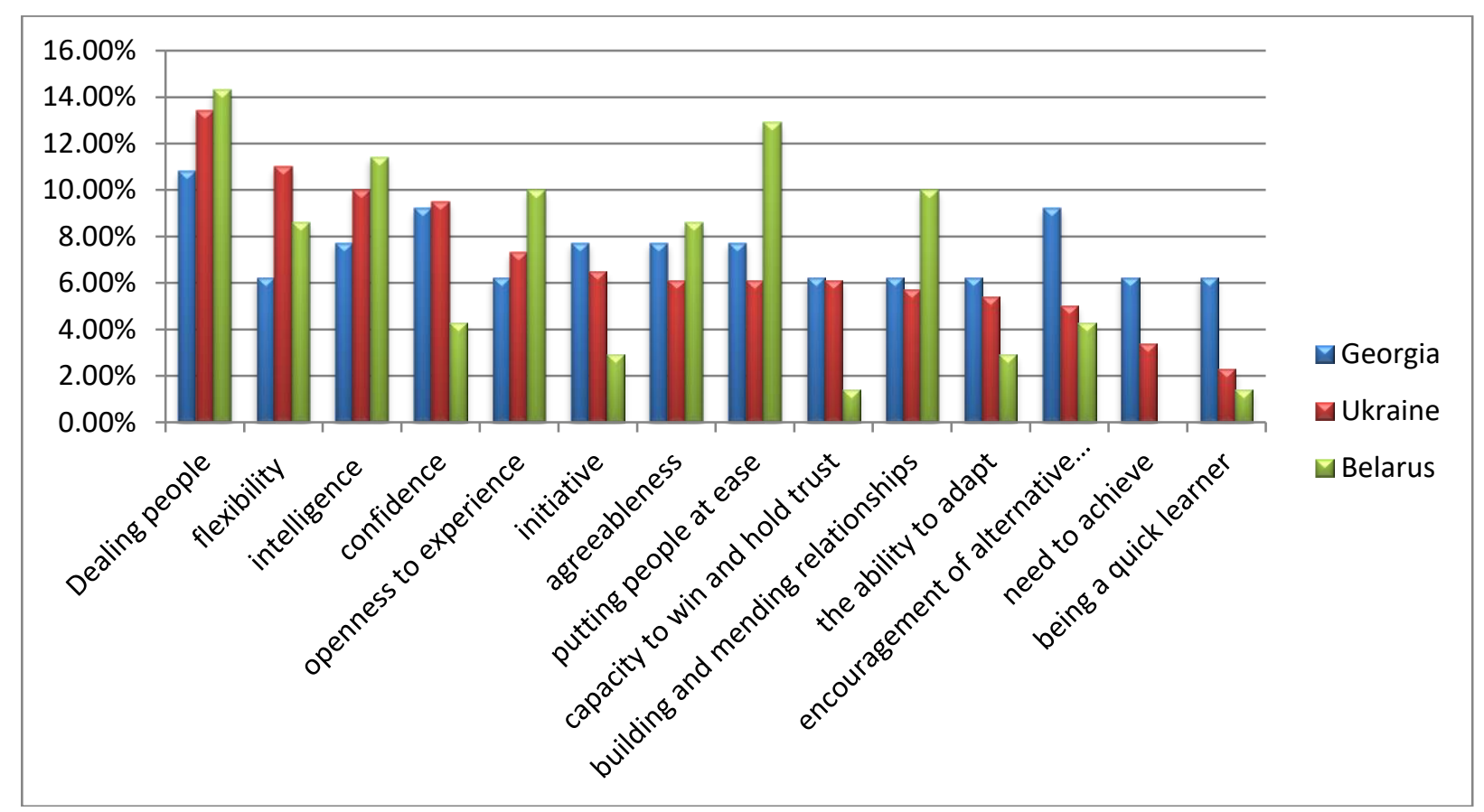

Picture 3

Erasmus Mundus PhD leadership skills as defined by programme alumni

Have the Erasmus Mundus objectives been met in terms of employability, cooperation and collaboration?

$31,3 \%$ of leaders the respondents consulted in general issues now occupy a leadership position at home university, $25 \%$ stayed at their universities, but do not work on a leadership position, 6,3\% occupy a leadership position, but changed their place of work, $18,8 \%$ occupy a position which is not a leadership one, in an institution other than home university.

$25 \%$ of people that gave information about Poland to our respondents occupy a leadership position at home university, 37,5\% work at their home university, but not on a leadership position, while $12,5 \%$ changed their place of work, but their position is not a leadership one.

Out of the people, giving our respondents academic assistance, 31,3\% occupy a leadership position at home university, 31,3\% occupy a position which is not a leadership one, at home university, $12,5 \%$ occupy a leadership position in an institution other than home university, another $12,5 \%$ occupy a position which is not a leadership one, in an institution other than home university, and 6,3\% of such people are unemployed. 
$43,8 \%$ of people, giving assistance in research, now occupy a leadership position at home university, $12,5 \%$ occupy a position which is not a leadership one, at home university, 18,8\% occupy a leadership position in an institution other than home university, 6,3\% occupy a position which is not a leadership one, in an institution other than home university, and 6,3\% are unemployed.

Not any person, who helped our respondents to solve their personal problems, occupies a leadership position either at home or other university. $43,8 \%$ occupy a position which is not a leadership one, at home university, $12,5 \%$ occupy a position which is not a leadership one, in an institution other than home university, and 31,3\% of them are unemployed.

Concerning people organizing informal events, only 6,7\% occupy a leadership position at home university, $46,7 \%$ occupy a position which is not a leadership one, at home university, 13,3\% occupy a leadership position in an institution other than home university, $6,7 \%$ occupy a position which is not a leadership one, in an institution other than home university, and $20 \%$ are unemployed.

\section{Conclusions}

From the standpoint of social constructivism, leadership is a complex notion that is studied in different ways and requires different definitions depending on the sphere, social circle, and situation where it is needed. It consists of knowledge, skills, and attitudes, which are formed and developed in the zone of proximal development - under assistance and in the process of communication. For Erasmus Mundus PhD students of $A M U$, leadership is the interaction between leaders and followers among scholars educated at Adam Mickiewicz University of Poznan, that leads to positive changes in development of countries and reaching European standards.

Though cultural background influences some shades of understanding the notion of leadership, "schemas" of leadership of representatives of different social groups have more in common, than differences. The main leadership skill for representatives of all the studied nationalities is dealing with people. The importance of other skills differs depending on the nationality of a person.

As to the specifics of forming understanding of leadership in a multicultural environment, it appears to be much more complex than the one in a monocultural environment. The Erasmus Mundus participants are all the time exposed to situations when they require assistance, and receive this assistance from people of various nationalities and positions. All those people become models of leaders that form their multicultural and multileveled understanding of leadership.

As leadership consists of knowledge, skills, and attitudes, we explain how the Erasmus Mundus programme influences all of them:

- During the programme, knowledge is formed in the zone of proximal development, which is, from the standpoint of social constructivism, the best way to gain and retain knowledge.

- During the programme PhD students find positive changes in their personal skills, as well as gain some new ones, which can be proved by the words of the focus group interview participants.

- The atmosphere of AMU university provides good conditions for interaction and learning, also promotes personal changes of the participants, and motivates them to change their societies, forming their positive attitude to leadership and making them act like leaders after the programme, providing those changes.

And finally, as any other programme, Erasmus Mundus also has a way to improvement. The governments and universities are not always ready for the changes the 
programme alumni want to provide. Not all the people that used to be leaders for programme participants (among them are programme coordinators, academic supervisors, PhD students, university staff) stayed at their home universities, not many occupy leadership positions, and lot of leaders became unemployed. The text of the article suggests some of the probable changes that could be provided, but a lot needs further research.

\section{Acknowledgements}

The paper was written within the EMINENCE 2 Erasmus Mundus Programme. I am thankful to my AMU programme coordinator Nune Srapyan, academic supervisor Justyna Hadas for the assistance, and to all present Erasmus Mundus PhD students and alumni, who took part in the focus interview or filled in the questionnaire.

\section{References:}

1. Bass, B. and Stogdill, R. (1981). Handbook of leadership. 1st ed. New York: Free Press. Bass, B. M., Stogdill, R. M. (1990). Bass Stogdill's Handbook of Leadership: Theory, Research, and Managerial Applications. 3rd ed. New York: Free Press.

2. Billsberry, J. (2009). The Social Construction of Leadership Education. Journal of Leadership Education, 8(2), pp.1-9.

3. Coleman, M. and Briggs, A. (2002). Research methods in educational leadership and management. 1st ed. London: P. Chapman Pub.

4. Copeland, L. (1942). The World's great speeches. 1st ed. Garden City, N.Y.: Garden City Pub. Co.

5. Edmunds J. Edsel (2005). The Triangle of Success. Bloomington, IN: AuthorHouse.

6. Ghiselli, E. (1971). Explorations in managerial talent. 1st ed. Pacific Palisades, Calif: Goodyear Pub. Co.

7. Grint, K. (1997). Leadership: Classical, contemporary, and critical approaches. Oxford: Oxford University Press.

8. Growing leaders: Grow Tomorrow`s Leaders Today (2017) [online] Available at: http://growingleaders.com/blog/four-lost-qualities-must-build-students-today/ [Accessed 4 May 2017].

9. Guidelines For Applicants. Erasmus Mundus (2017) [online] Available at: http:/ / mundus.amu.edu.pl/EMINENCEII/Guidelines\%20for\%20Applicants\%20EMINENCE\%20$\% 203 \% 20$ rd \%20\%20call.pdf [Accessed 4 May 2017].

10. Gupta, A. (2005). Leadership in a Fast-Paced World - An Interview with Ken Blanchard (1st ed., vol. 20, pp.7-11): Mid American Journal of Business.

11. Jennings, H. (1944). Leadership - A Dynamic Redefinition. Journal of Educational Sociology, 17(7), p.431.

12. Gardner, J. (1993) On Leadership. 1st ed. New Zork: Simon and Schuster.

13. Kanter, A. (1983). Defense politics. 1st ed. Chicago: University of Chicago Press.

14. Leslie J. B. (2017). The Leadership GAP : What you need, and don't have, when it comes to leadership talent. Center for Creative Leadership [online] Available at: http://www.ccl.org/leadership/pdf/research/leadershipGap.pdf [Accessed 4 May 2017].

15. Lussier, R. and Achua, C. (2015). Leadership. 1st ed. Boston, MA: Cengage Learning.

16. Misumi, J. and Peterson, M. (1985). The behavioral science of leadership. 1st ed. Ann Arbor: University of Michigan Press.

17. Multidisciplinary Individual Studies in Humanities and Social Sciences. Adam Mickiewicz University of Poznan (2017) [online] Available at: https://www.google.pl/search?q=mish+uam+pozna\% C5\%84\&oq=mish\&aqs=chrome.2.69i57j0j69 i5912j012.3193j0j9\&sourceid=chrome\&ie=UTF-8 [Accessed 4 May 2017].

18. Rost, J. (1991). Leadership for the Twenty-First Century. New York: Praeger.

19. Rowley, T. and Moldoveanu, M. (2003). When Will Stakeholder Groups Act? An Interest- and IdentityBased Model of Stakeholder Group Mobilization. The Academy of Management Review, 28(2), p. 204. 
20. Sandberg, J. (2001). The constructions of social constructionism. In S. E. Sjöstrand, J. Sandberg, and M. Tyrstrup (Eds.), Invisible Management: The Social Construction of Leadership (pp. 28-48). London: Thomson Learning.

21. Thorndyke, P. (1981). Schema theory as a guide for educational research. 1st ed. Santa Monica, Calif.: Rand Corp.

22. Vygotsky, L. S. (1978). Mind in society: The development of higher psychological processes. Cambridge, MA: Harvard University Press.

23. Vygotsky, L. S. (1980). Mind in society: The development of higher psychological processes. Cambridge, MA: Harvard University Press

Weiss, P. (1986). Philosophy in process. 1st ed. Carbondale: Southern Illinois University Press

Received: November, 1

Accepted: November, 28 